\title{
What Does the Federal Reserve's Economic Value Model Tell Us About Interest Rate Risk at U.S. Community Banks?
}

\author{
Gregory E. Sierra and Timothy J. Yeager
}

I

nterest rate risk at commercial banks is the risk that changes in interest rates will adversely affect income or capital. Such risk is an inherent part of banking because banks typically originate loans with longer maturities than the deposits they accept. This maturity mismatch between loans and deposits causes the net interest margin (NIM) the spread between loan rates and deposit ratesto fall when interest rates rise, because interest rates on deposits adjust more quickly than interest rates on loans. Further, when interest rates rise, the economic value of longer-term instruments (assets) falls by more than the economic value of shorterterm instruments (liabilities), thus reducing the bank's capital.

Bankers became increasingly concerned about interest rate risk following the savings and loan $(S \& L)$ crisis. In the early 1980s, many thrifts became insolvent after interest rates rose sharply, setting off a crisis that eventually required a $\$ 150$ billion taxpayer bailout (Curry and Shibut, 2000). Thrifts were particularly vulnerable to interest rate risk because of the large maturity mismatch that resulted from using short-term deposits to fund long-term home loans. Nevertheless, banks devoted considerable resources to measuring and managing their exposure to interest rate risk. Many regional and money-center banks implemented elaborate models to measure their exposure and began to use sophisticated asset and liability management to manage their risk.

Bank supervisors also were challenged to stay abreast of the industry's ability to take on interest rate risk, and they responded with three related initiatives. First, bank examiners received capital markets training to help them understand better the techniques for measuring and managing interest rate risk. Second, bank supervisors explicitly incorporated interest rate risk into their ratings system in 1997, transforming the "CAMEL" rating system into "CAMELS." 1 The "S" rating stands for a bank's sensitivity to market risk, which includes interest rate risk and exposure to trading account assets, exchange rates, and commodity prices. ${ }^{2}$ The third supervisory initiative was to develop a measure of interest rate risk that examiners could use to riskscope a bank - that is, to pinpoint the areas of the bank that warrant closer scrutiny - and to conduct off-site surveillance. Economists at the Board of Governors of the Federal Reserve System developed a proprietary economic value of equity model called the economic value model (EVM), which is a durationbased estimate of interest rate sensitivity for each U.S. commercial bank (Houpt and Embersit, 1991; Wright and Houpt, 1996). The Federal Reserve operationalized the model in the first quarter of 1998 by producing a quarterly report (called the Focus Report) for each bank. The Focus reports are the confidential supervisory reports that provide the detailed output of the Fed's EVM.

The EVM's interest rate sensitivity assessment is most relevant for community banks, which we define as those with less than $\$ 1$ billion in assets and no interest rate derivatives. Larger banks often

\footnotetext{
1 Board of Governors, SR 96-38. CAMEL stands for capital adequacy, asset quality, management, earnings, and liquidity.

2 For the majority of banks that have no trading accounts or foreign currency exposures, market risk and interest rate risk are equivalent.
}

Gregory E. Sierra is an associate economist and Timothy J. Yeager is an economist and senior manager at the Federal Reserve Bank of St. Louis. The authors thank workshop participants at the Federal Reserve Board of Governors, the Federal Reserve Banks of Kansas City and Chicago, the Federal Reserve System Capital Markets Working Group 2003 Conference, the Olin School of Business at Washington University in St. Louis, and the University of Missouri-St. Louis for their comments. The authors are especially grateful for comments from Nick Dopuch, Jim Embersit, Greg Geisler, Rohinton Karanjia, David Kerns, and Jim O’Brien and also thank their colleagues at the Federal Reserve Bank of St. Louis—Alton Gilbert, Tom King, Julie Stackhouse, Mark Vaughan, and David Wheelock—for their insightful comments.

Federal Reserve Bank of St. Louis Review, November/December 2004, 86(6), pp. 45-60.

(C) 2004, The Federal Reserve Bank of St. Louis. 
have derivatives or other balance-sheet complexities that the EVM ignores, making the output from the EVM more questionable. The EVM also is more appropriately applied to community banks because community banks are examined less often than larger banks and the EVM is usually the only tool for off-site interest rate risk assessment available to examiners for those banks. Community banks devote fewer resources to modeling and measuring their interest rate risk than do regional and money-center banks, which normally have full-time staff devoted to such tasks. Consequently, examiners of larger institutions usually have access to more sophisticated and often more timely information than that provided by the EVM.

This paper investigates the effectiveness of the EVM by examining whether model estimates are correlated with community bank measures of interest rate sensitivity during recent periods of both rising and falling interest rates. Because the model is relatively new, it has yet to be validated against actual bank performance. The Federal Open Market Committee (FOMC) increased the federal funds rate six times in 1999 and 2000, and then lowered the federal funds rate 12 times in 2001 and 2002. A strong correlation between the EVM's estimate of interest rate sensitivity and measures of interest rate risk during these periods would suggest that the model provides a useful surveillance tool to community bank supervisors.

We find that estimates from the Fed's EVM are correlated with the performance of U.S. community banks in the manner the EVM suggests. Specifically, the banks that the EVM identifies as the most liability sensitive - those most sensitive to rising rates - show the biggest deterioration in performance during the period of rising interest rates between 1998 and 2000. The most liability-sensitive banks also show the greatest improvement in performance measures during the 2000-02 period of falling rates. The evidence indicates, then, that the EVM is a useful tool for supervisors interested in identifying the minority of banks that are highly sensitive to interest rate changes.

\section{RELATED LITERATURE}

Researchers have examined the interest rate sensitivity of depository institutions in some detail. There are two general lines of inquiry. The first line of inquiry asks whether depository institutions are exposed to interest rate changes and, if so, how large is that exposure on average? The motivation for this research often is to assess the impact that monetary policy or unexpected inflation might have on financial intermediation. Most studies measure interest rate sensitivity by regressing the firm's stock return on a market index and an interest rate. Flannery and James (1984), Aharony, Saunders, and Swary (1986), Saunders and Yourougou (1990), Yourougou (1990), and Robinson (1995) find that bank stock prices react to (unexpected) interest rate changes. A major limitation of this research is that the vast majority of U.S. banks are excluded from the analysis because they have no publicly traded equity. Flannery (1981, 1983) constructs a model that estimates the effect of rate changes on a bank's net operating income. The model has the added advantage that it indirectly estimates the maturities of the assets and liabilities. Flannery finds that the impact of rate changes on long-run bank earnings is small, averaging only 5.6 percent of net operating earnings. He also finds that banks are slightly asset sensitive; that is, profits increase with rising interest rates. These results, however, contradict much of the literature-including some of Flannery's later work - which shows that banks tend to be exposed to rising rates.

A second line of inquiry attempts to isolate a bank-specific measure of interest rate risk to separate banks by their interest rate sensitivity. Regulators are interested in this process because bank-specific measures provide opportunities to identify high-risk banks. Flannery and James (1984) construct a oneyear gap measure and quantify the correlation between this measure and the portion of a bank's stock return driven by interest rate changes. They find that this simple maturity variable has statistically significant explanatory power. Gilkeson, Hudgins, and Ruff (1997) use output from a regulatory gap model for thrifts between 1984 and 1988. They also find a statistically significant correlation between net interest income and the one-year gap measure. Robinson and Klemme (1996) find that bank holding companies with relatively high levels of mortgage activity have higher degrees of interest rate sensitivity than other bank holding companies, as reflected by changes in stock prices. Finally, Lumpkin and O'Brien (1997) construct a comprehensive measure of thrifts' portfolio revaluations caused by interest rate changes. They fail to find evidence that such revaluations influence stock returns beyond the influence already captured by more general movements in interest rates.

This article adds to the evidence that banks are liability sensitive, though the interest rate sensitivity, 
on average, is small. Our results are consistent with Gilkeson et al. (1997) and show that even accountingbased measures of interest rate sensitivity can have significant explanatory power to aid bank supervisors in risk-scoping and monitoring the interest rate exposure of commercial banks. Our results imply, as well, that large rate increases are unlikely to have significant adverse effects on the banking industry, which is also consistent with previous literature.

\section{A MEASURE OF RATE SENSITIVITY: THE EVM}

Interest rate risk is the product of a bank's rate sensitivity and subsequent rate changes. If rate changes are unpredictable, then measurement of a bank's rate sensitivity is crucial to monitoring and controlling interest rate risk. Models that measure interest rate sensitivity fall into one of two categories. Earnings-at-risk models estimate changes in a bank's net interest margin or net income in response to changes in interest rates. Equity-at-risk models estimate changes in a bank's market value of equity, or its economic capital, in response to changes in interest rates.

Federal Reserve economists used the concept of duration to develop an equity-at-risk model of a bank's interest rate sensitivity. Duration is the present-value weighted-average time to maturity of a financial instrument. ${ }^{3}$ Conceptually, it is the price sensitivity of a financial instrument to a change in interest rates. If, for example, the (modified) duration of a Treasury bond is -3.0 , the bond is projected to lose 3 percent of its value, given a 100-basis-point increase in interest rates. The price of a financial instrument with a larger duration will fluctuate more in response to interest rate changes than the price of an instrument with a smaller duration.

To ease banks' regulatory burden, the Fed's EVM uses call report data, most of which is recorded at historical cost (rather than marked to market). The EVM aggregates balance sheet items into various categories, an example of which is shown in Table 1 for a hypothetical bank. ${ }^{4}$ The model then matches each category with a proxy financial instrumentan instrument with a known market price that has a duration similar to those items in a given category-

\footnotetext{
3 A number of financial textbooks discuss duration in detail. See, for example, Saunders and Cornett (2003)

4 Table 1 is adapted from Wright and Houpt (1996). This table does not show the exact categories and risk weights used in the EVM.
}

and assigns a "risk weight." The risk weight for each category is the estimated change in economic value of those items, given a 200-basis-point instantaneous rise in rates. ${ }^{5}$ For example, the EVM places all fixedrate mortgage products that reprice or mature in more than five years into the same category. In this example, the risk weight for that category is -8.50 , indicating that the value of those mortgages are estimated to decline by 8.5 percent following an immediate 200-basis-point rate hike. The change in economic value is repeated for each balance sheet category. The predicted change in the economic value of equity, then, is the difference between the predicted change in assets and the predicted change in liabilities. The net change is scaled either by assets or equity. In this paper, we scale the change in equity by assets and refer to the output of the EVM as the "EVE" score. The example bank in Table 1 has an EVE score of -1.97 ; that is, the bank is expected to lose equity equal to 1.97 percent of assets when interest rates rise by 200 basis points.

The model's simplicity and generality make it a potentially powerful surveillance tool, but those same characteristics lead practitioners to question its usefulness. First, a precise economic-value-ofequity model would require an exact calculation of the duration for each financial instrument, which in turn requires detailed information on the cash flows and optionality of those instruments - data that the call reports do not contain. Because of this information limitation, the Fed's EVM may perform poorly for banks with a significant share of assets invested in complex instruments, such as collateralized mortgage obligations (CMOs) or callable securities, because their durations are more difficult to estimate. ${ }^{6}$ Should interest rates fall, CMOs, for example, may mature much more quickly than anticipated by the EVM because homeowners will exercise their refinancing option. The maturity of core deposits may be another source of error. A community bank in a rural area with strong ties to its depositors may have a duration of demand deposits that is significantly longer than the duration at larger urban banks because the rural customers are less likely to withdraw their funds should market rates increase. A

\footnotetext{
5 The (confidential) risk weights are derived by economists at the Board of Governors of the Federal Reserve System, and they do not change over our sample period.

6 The EVM also fails to account for derivatives, another class of complex instruments. To avoid any bias from this source, we eliminate from our sample banks with derivatives.
} 


\section{Table 1}

How Does an Accounting-Based Duration Model Work?

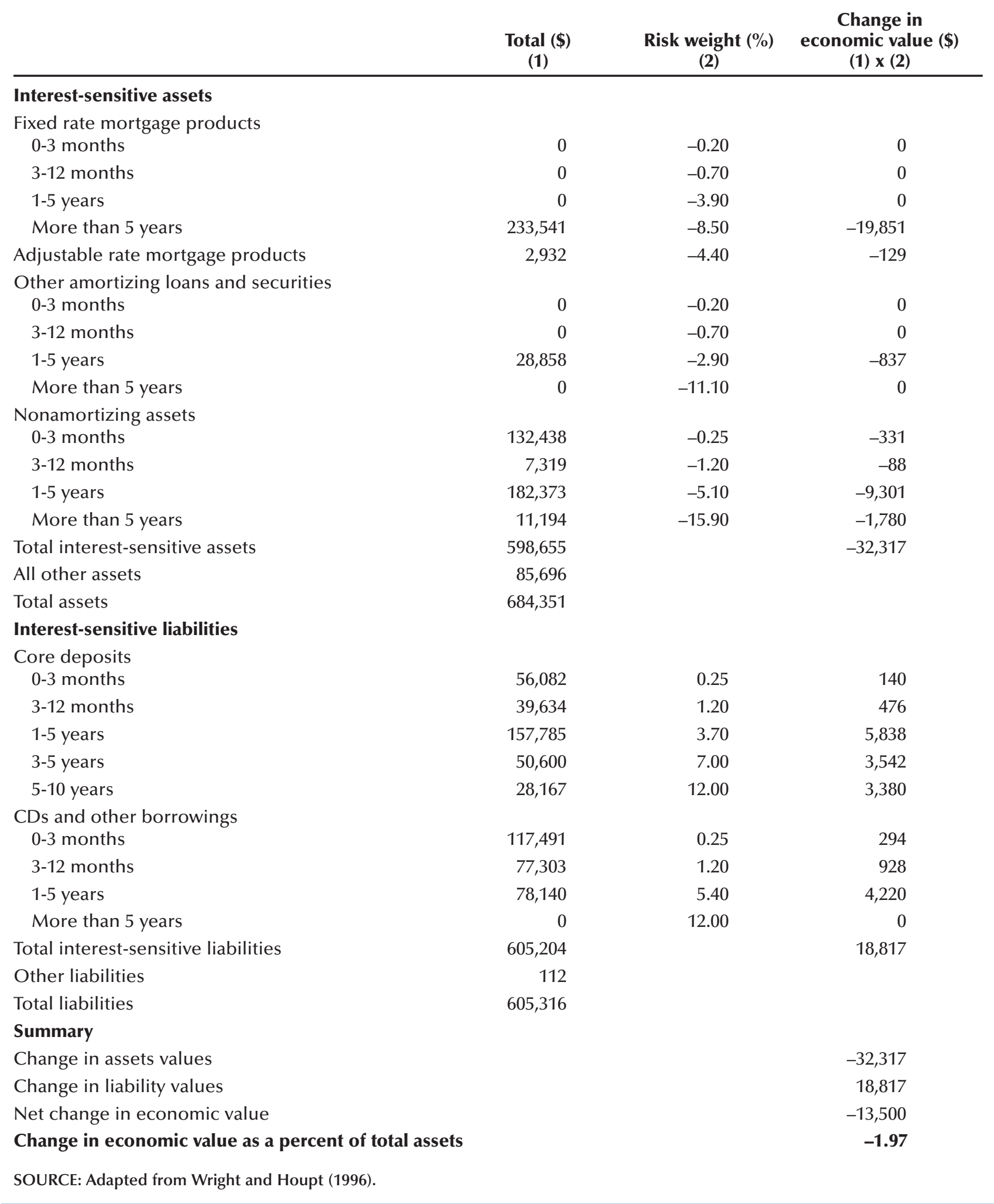


second reason to question the applicability of the EVM is that a precise equity-at-risk calculation requires current market prices on all balance sheet items because the estimated change in the value of an asset or liability is equal to the duration multiplied by its price. Strictly speaking, the term "economic value" in this context is a misnomer because the EVM uses book values as estimates of market prices. A third weakness is that the EVM simulates just one interest rate scenario. Specifically, the model projects changes to a bank's economic value of equity given an instantaneous 200-basis-point upward parallel shift in the yield curve. The model does not account for changes in the slope of the yield curve, nor does it simulate a reduction in interest rates.

Despite these weaknesses, the Fed's EVM still may serve as a useful measure of interest rate sensitivity for community banks. Even if the actual EVE score of a given bank is imprecise, the ordinal ranking of banks by EVE scores may help supervisors detect the outlier banks that are vulnerable to an interest rate shock.

\section{MEASURING THE IMPACT OF RATE CHANGES WITH ACCOUNTING DATA}

Tests of the ability of the EVM to measure interest rate sensitivity require assessments of bank performance following interest rate changes. The ideal performance indicator for testing the EVM is the change in the economic value of equity following a change in interest rates. In such a world, the ex post interest rate sensitivity of a bank could be measured via an econometric model by estimating the change in publicly traded equity due to the change in rates. Indeed, a number of studies have estimated in this manner the interest rate sensitivity of large banks.

Unfortunately, such data are available only for the approximately 300 bank holding companies with actively traded equity. To assess community bank performance following interest rate changes, we must rely exclusively on accounting information produced under generally accepted accounting principles (GAAP). Because we are limited to accounting data, our methodology simultaneously tests the usefulness of regulatory accounting information and the Fed's EVM. The adequacy of GAAP-based measures to capture interest rate risk is a question we leave for future research.

The accounting-based bank performance meas-

\footnotetext{
7 Clearly, this analysis is suggestive because other factors such as the 2001 recession may have affected NIM.
}

ures we utilize include changes in the NIM, return on assets (ROA), and the book value of equity (BVE). NIM is the ratio of net interest income divided by average earning assets, ROA (as defined here) is net income (before extraordinary items) divided by average assets, and BVE is simply the accounting value of total equity capital divided by total assets. The change in BVE is a straightforward, albeit imperfect, performance measure to assess the EVM because the EVM directly estimates the change in equity given an interest rate change. Unlike the economic value of equity, BVE will change slowly as items are gradually marked to market (recorded at market prices). The usefulness of NIM and ROA require further explanation.

Although the theoretical link between earnings and a duration-based equity-at-risk model is somewhat loose, an empirical relationship should be discernable over a large number of observations. Banks that the EVM estimates to be vulnerable to rising interest rates (those with large negative EVE scores) are those that have weighted-average asset durations greater than weighted-average liability durations. When interest rates rise, assets decline in value more than liabilities, reducing the bank's economic capital. Because maturity is one component of duration, those same banks should be liability sensitive, on average, such that liabilities tend to mature or reprice faster than assets. In the short term, interest expense on liabilities will tend to increase more quickly than interest income on assets in a rising rate environment, reducing the NIM. The change in ROA captures not only the effect on NIM, but also any other noninterest impact of rate changes on earnings. Loan origination income might decline, for example, when interest rates rise, because refinancing activity slows. We expect, therefore, that banks with large negative values of EVE will exhibit a more pronounced deterioration in these income measures when interest rates rise, and those same banks will see a larger surge in income when interest rates fall.

A cursory look at bank NIMs suggests that banks are modestly rate sensitive. Figure 1 plots the effective federal funds rate on the right axis and the fourquarter moving average NIM on the left axis. We employ the four-quarter moving average to control for the seasonality in the data. Although the effective federal funds rate fluctuated by more than 400 basis points between 1998 and 2002, the average NIM of U.S. community banks changed little, staying within a range of about 20 basis points. ${ }^{7}$ 


\section{Figure 1}

\section{NIM and the Effective Federal Funds Rate: Commercial Banks Are, on Average, Liability Sensitive}

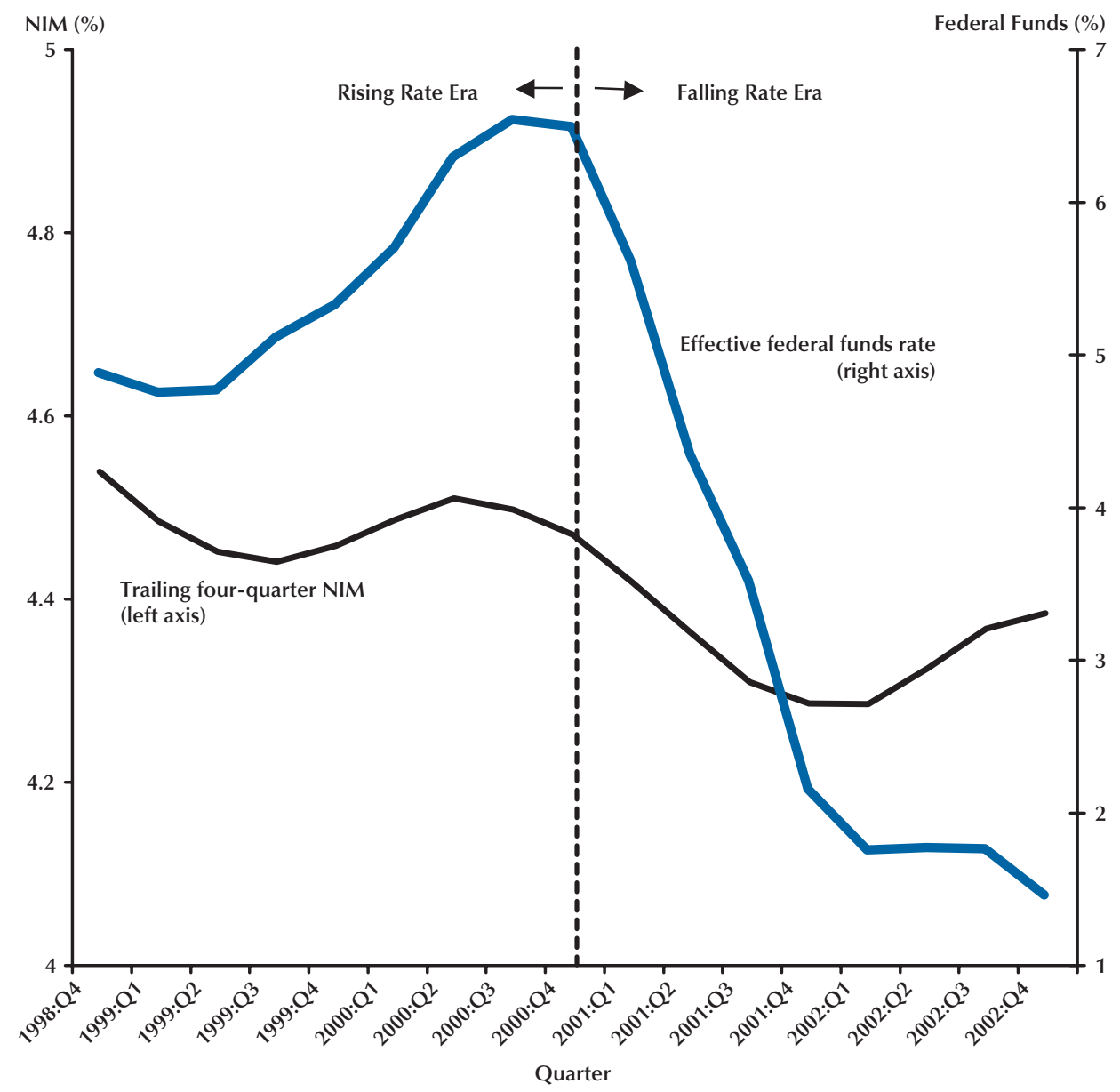

NOTE: We plot the trailing four-quarter NIM for banks with less than \$1 billion in total assets and the effective quarterly federal funds rate. The movement in NIM is consistent with commercial banks being modestly rate sensitive on average.

\section{EMPIRICAL ANALYSIS OF THE ECONOMIC VALUE MODEL}

We test the ability of the Fed's EVM to distinguish interest rate sensitivity differences among U.S. community banks by comparing the measured interest rate sensitivity of the EVM with accounting performance measures. Observance of a bank's ex post experience of interest rate risk requires an interest rate change, a degree of rate sensitivity, and a time period sufficiently long enough for the interest rate risk to flow through the accounting data. ${ }^{8}$

To control for rate changes and time lags, we split the sample into two periods: a period of rising rates and a period of falling rates. Doing this, we ensure that the banks are hit by rate changes in the same direction, as opposed to offsetting rate changes. We chose the fourth quarter of 1998 through the fourth quarter of 2000 as the rising rate period and the fourth quarter of 2000 through the fourth quarter of 2002 as the falling rate period. The quarterly effec-

8 Results not presented here indicate that the Fed's EVM, using quarterly accounting data, cannot distinguish effectively between banks with different rate sensitivities. This result is likely a combination of the accounting data that react with lags and low absolute levels of interest rate risk at most commercial banks. In tests using stock market returns, the Fed's EVM can distinguish among firms on a quarterly basis (Sierra, 2004). 
tive federal funds rate increased 161 basis points in the first period and fell 503 basis points during the second period. Moreover, the yield curve steepened considerably in the falling rate period. The yield spread between the 10-year and 6-month Treasuries averaged 27 basis points between year-ends 1998 and 2000 and 235 basis points between year-ends 2000 and 2002. Yield spreads on Treasuries more consistent with bank asset and liability durations also increased in the later era. The spread between the 3-year and 1-year Treasuries averaged 27 basis points in the former period and 89 basis points in the later period. Hence, we should expect larger changes in bank performance measures during the falling rate era.

Our bank performance measures include the changes in NIM, ROA, and BVE over the relevant time period. We compute the changes in NIM and ROA using four-quarter averages to control for seasonality. For example, the rising interest rate environment begins in the fourth quarter of 1998 and ends in the fourth quarter of 2000. The change in NIM, then, is the trailing four-quarter NIM ending in the fourth quarter of 2000 less the trailing four-quarter NIM ending in the fourth quarter of 1998 . We perform ordinary least-squares regression analysis, matchedpairs analysis, and correlation analysis with the "S" rating to test the EVM.

\section{Bank Sample}

Our bank sample is split into the rising rate era and the falling rate era. We exclude banks with more than $\$ 1$ billion in assets in any given quarter, de novo banks (those less than five years old), and banks that merged during the respective time period. ${ }^{9}$ In addition, we eliminate the very smallest banksthose with less than $\$ 5$ million in assets-and banks with measures that are extreme outliers, because these values fall outside of the realm of reasonable values for typical banks. ${ }^{10}$ For each era, the sample

9 Excluding banks involved in mergers potentially creates a survivorship bias. The bias would emerge if banks with high interest rate risk are involved in mergers to a greater extent than banks with low interest rate risk. We empirically examine this bias by comparing the average EVE scores of the merger banks in the quarters before merger with the average EVE scores of the sample banks. We find that the mean EVE scores from the two groups are not significantly different from one another, suggesting that survivorship bias is not important.

${ }^{10}$ We remove banks with NIM, ROA, BVE or nonperforming loans greater than the 99.75th percentile. We also remove banks with ROA below the 0.25 th percentile. Banks with asset growth rates less than or equal to -100 percent are excluded. Finally, we exclude banks with a NIM, BVE, or nonperforming loan ratio less than zero. contains about 6,000 banks and represents about 11 percent of all commercial banking assets. Descriptive statistics for the full-regression sample appear in Table 2.

As Table 2 reveals, changes in the accounting performance measures - the dependent variablesare modest. Mean NIM decreased 3 basis points in the rising rate era (Panel A) and fell again by 15 basis points in the falling rate era (Panel B). Changes in ROA were smaller, with ROA essentially unchanged in both the rising and falling rate eras. BVE declined by 2 basis points in the rising rate environment and increased by 22 basis points in the falling rate environment.

Table 2 also lists summary statistics for the independent variables, and EVE is the independent variable of primary interest. We multiply EVE by -1 to make its interpretation more intuitive. Because the Fed's EVE measure becomes more negative as the liability sensitivity of the bank increases, EVE and exposure to rising interest rates are inversely related. Flipping the sign on the EVE measure allows us to associate larger EVE values with greater exposure to rising interest rates. The mean EVE in Panel A of Table 2 is 0.87 , which says that the average bank is predicted to lose 0.87 percent of its net economic asset value given a 200-basis-point parallel shift in the yield curve. The mean EVE in the falling rate era is 0.99 percent. The average sample bank, therefore, is estimated to be liability sensitive.

\section{The Regression Model}

We use regression analysis to assess the average correlation between a bank's EVE and a change in NIM, net income, and BVE, for a given change in interest rates. EVE is computed as the average of each quarterly EVE value within the given time period. We use the average EVE value rather than the beginning-of-period EVE value because we are more interested in the correlation of EVE with the dependent variables, and less interested in the predictive power of EVE in a given quarter. ${ }^{11}$ The average EVE score accounts for changes in EVE during the two-year sample period, an important factor if bank managers endogenously alter their interest rate sensitivity as interest rates begin to move in a particular direction. The EVE coefficient should be negative in the rising rate era because rising rates reduce earnings and equity at liability-sensitive banks. Con-

\footnotetext{
${ }^{11}$ As a robustness check, we ran the regressions using beginning-of-
} period EVE and obtained qualitatively similar results. 


\section{Table 2}

\section{Descriptive Statistics of Regression Samples}

Panel A: Rising interest rate era, 1998:Q4-2000:Q4 (6,016 observations)

\begin{tabular}{lrrrrrrr} 
& Mean & $\begin{array}{r}\text { Standard } \\
\text { deviation }\end{array}$ & Minimum & Q1 & Median & Q3 & Maximum \\
\hline NIM & 4.20 & 0.73 & 0.00 & 3.73 & 4.14 & 4.60 & 8.57 \\
ROA & 1.19 & 0.58 & -3.15 & 0.90 & 1.17 & 1.46 & 5.94 \\
BVE & 10.36 & 3.46 & 3.06 & 8.09 & 9.55 & 11.70 & 51.36 \\
Change in NIM & -0.03 & 0.47 & -4.81 & -0.24 & -0.03 & 0.19 & 4.69 \\
Change in ROA & -0.01 & 0.51 & -4.94 & -0.20 & -0.01 & 0.18 & 5.19 \\
Change in BVE & -0.02 & 1.59 & -20.38 & -0.66 & 0.01 & 0.67 & 21.49 \\
EVE & 0.87 & 1.24 & -3.26 & 0.03 & 0.78 & 1.57 & 8.85 \\
NPL & 0.56 & 0.67 & 0.00 & 0.11 & 0.34 & 0.76 & 6.06 \\
LNTA & 11.22 & 0.94 & 8.59 & 10.56 & 11.20 & 11.85 & 13.81 \\
AGR & 11.35 & 12.32 & -92.49 & 3.97 & 10.09 & 17.66 & 86.07
\end{tabular}

Panel B: Falling interest rate era, 2000:Q4-2002:Q4 (5,773 observations)

\begin{tabular}{lrrrrrrr} 
& Mean & $\begin{array}{r}\text { Standard } \\
\text { deviation }\end{array}$ & Minimum & Q1 & Median & Q3 & Maximum \\
\hline NIM & 4.18 & 0.77 & 0.24 & 3.69 & 4.11 & 4.60 & 8.74 \\
ROA & 1.20 & 0.62 & -3.25 & 0.86 & 1.17 & 1.50 & 7.86 \\
BVE & 10.38 & 3.52 & 4.51 & 8.02 & 9.44 & 11.77 & 51.24 \\
Change in NIM & -0.15 & 0.63 & -5.98 & -0.45 & -0.10 & 0.21 & 4.42 \\
Change in ROA & -0.02 & 0.58 & -5.63 & -0.25 & 0.00 & 0.25 & 5.64 \\
Change in BVE & 0.22 & 1.54 & -16.56 & -0.44 & 0.27 & 0.97 & 10.59 \\
EVE & 0.99 & 1.25 & -3.54 & 0.15 & 0.86 & 1.70 & 10.10 \\
NPL & 0.66 & 0.77 & 0.00 & 0.13 & 0.41 & 0.91 & 6.41 \\
LNTA & 11.34 & 0.95 & 8.67 & 10.69 & 11.32 & 12.00 & 13.80 \\
AGR & 12.64 & 11.92 & -86.17 & 5.78 & 11.67 & 18.71 & 78.62
\end{tabular}

NOTE: Change in NIM: the trailing four-quarter NIM at the end of the period less the trailing four-quarter NIM at the start of the period. Change in ROA: the trailing four-quarter ROA at the end of the period less the trailing four-quarter ROA at the start of the period. Change in BVE: BVE at the end of the period less BVE at the start of the period. EVE: average over all quarters in the given era of Fed EVE score scaled by total assets. NPL: average nonperforming loans to total assets in the given era. LNTA: the natural log of average total assets in the given era. AGR: the growth rate of total assets during the given era.

versely, the EVE coefficient should be positive in the falling rate era.

In the regressions, we attempt to control for factors other than interest rate changes that could influence income and equity ratios. Specifically, we include the ratio of nonperforming loans to total assets (NPL) - loans that are 90 days or more past due or are no longer accruing interest-as a credit risk control variable because nonperforming loans can directly and indirectly affect all three dependent variables. Most nonperforming loans do not accrue interest, which means that interest income, and hence NIM and ROA, are lower than they otherwise would be. In addition, a higher ratio of nonperforming loans may be associated with changes in asset quality, which would cause a bank to set aside more provisions and lower ROA. Finally, the change in BVE is smaller if net income and, hence, retained earnings are smaller. We expect the signs of the nonperforming loans coefficients to be negative in both 
the rising and falling rate periods. The mean nonperforming loan-to-total-asset ratio is 0.56 percent in Panel A of Table 2 and 0.66 percent in Panel B of Table 2.

We also control for bank size by including the natural log of total assets in the regression. NIM, net income, and BVE may respond to the economic environment differently at larger banks than at smaller banks. For example, changes in interest rates may trigger the use of lines of credit, which are more prevalent at larger institutions. The sign of this coefficient could be positive or negative.

Asset growth is an explanatory variable that controls for portfolio turnover. More rapid asset growth brings assets and liabilities onto the books faster at market prices, which may either exacerbate or dampen the sensitivity of earnings and BVE to changes in interest rates. Asset growth will exacerbate interest rate sensitivity if the new assets and liabilities reinforce or increase the bank's interest rate position. Conversely, asset growth will dampen sensitivity if the new assets and liabilities mitigate the bank's interest rate position. The average EVE score will partially capture these asset-growth effects, but the EVE scores are not asset weighted. The signs of the asset-growth coefficients, therefore, are uncertain. Table 2 shows that banks grew quickly in each sample period. The mean growth rate in the rising rate era is 11.35 percent; asset growth in the falling rate era is 12.64 percent. The standard deviation of asset growth is also quite large, exceeding 11 percent in both rate eras.

We use ordinary least squares to run crosssectional regressions on the following model:

(1)

$\Delta Y_{i}=\alpha_{0}+\alpha_{1} E V E_{i}+\alpha_{2} N P L_{i}+\alpha_{3} L N T A_{i}+\alpha_{4} A G R_{i}+\varepsilon_{i}$,

where $\Delta Y_{i}$ represents the change in the dependent variable (NIM, ROA, or BVE) of bank $i, L N T A$ is the natural log of total assets, and $A G R$ is asset growth. The dependent variables are computed as the endof-period value less the beginning-of-period value, while the independent variables (except asset growth) are the quarterly averages over the time period. Asset growth is simply the percentage change in assets over the period. We report two specifications of equation (1). Model 1 excludes asset growth; model 2 includes asset growth. For both models, the primary focus is on the EVE coefficient.

\section{Regression Results}

Regression results in Table 3 show that the Fed's EVM is indeed correlated with the accounting performance measures. In the rising rate era, we expect the high-EVE banks to perform worse than low-EVE banks. Specifically, the EVE coefficient should be negative for each regression presented in Panel A of Table 3. Across the columns of the EVE row in Panel A, the EVE coefficients are negative and statistically significant for every specification and every dependent variable. The results from model 2 indicate that a bank with an EVE score 1 percentage point higher than another bank would experience, all else equal, a drop in NIM, ROA, and BVE equal to $5.0,5.4$, and 18.5 basis points, respectively, over the two-year period. Put another way, the results imply that for the average bank, which has an EVE score of 0.87, NIM, ROA, and BVE were about $4.4(5.0 \times 0.87)$, 4.7 , and 16.1 basis points lower, respectively, than they would have been had the bank had an EVE score of zero. The results in Panel A are consistent with the ability of the Fed's EVM to identify a bank's sensitivity to rising rates.

In the falling rate era, high-EVE banks are projected to be more liability sensitive such that the high-EVE banks should perform better than lowEVE banks. If EVE is able to distinguish effectively between banks with high and low liability sensitivity, the EVE coefficients should be positive in Panel B of Table 3. Across the columns of the EVE row in panel B, the EVE coefficients are positive and statistically significant for both model specifications and each dependent variable. The EVE coefficients imply that changes in NIM, ROA, and BVE over the two-year period are expected to increase $15.2,8.6$, and 3.7 basis points, respectively, for each 1-percentagepoint increase in EVE. The results in Panel B are consistent with the ability of the Fed's EVM to identify banks that are the most sensitive to falling interest rates.

The EVE coefficients for NIM and ROA are much larger in Panel B of Table 3 than in Panel A, a result that most likely reflects the greater interest rate changes in the falling rate era. Recall that the federal funds rate fell 503 basis points in the falling rate era, which is 4.3 times the 116-basis-point rise in the rising rate era. In addition, the average yield spread between the 1- and 3-year Treasuries increased 3.5 times relative to the rising rate era. According to model 2, a bank with an EVE score 1 percentage point higher than another bank in the rising rate era 


\section{Table 3}

\section{Regression Analysis of the Fed's Economic Value Model}

Panel A: Rising Interest Rate era, 1998:Q4-2000:Q4 (6,016 observations)

Dependent Variable

\begin{tabular}{|c|c|c|c|c|c|c|}
\hline \multirow[b]{2}{*}{ Variable } & \multicolumn{2}{|c|}{ Change in NIM } & \multicolumn{2}{|c|}{ Change in ROA } & \multicolumn{2}{|c|}{ Change in BVE } \\
\hline & Model 1 & Model 2 & Model 1 & Model 2 & Model 1 & Model 2 \\
\hline $\begin{array}{l}\text { Intercept } \\
\text { (p value) }\end{array}$ & $\begin{array}{c}0.656 \\
(0.000)\end{array}$ & $\begin{array}{c}0.421 \\
(0.000)\end{array}$ & $\begin{array}{c}0.230 \\
(0.002)\end{array}$ & $\begin{array}{c}0.098 \\
(0.205)\end{array}$ & $\begin{array}{c}1.051 \\
(0.000)\end{array}$ & $\begin{array}{c}-0.344 \\
(0.000)\end{array}$ \\
\hline $\begin{array}{l}\text { EVE } \\
\text { ( } p \text { value) }\end{array}$ & $\begin{array}{c}-0.044 \\
(0.000)\end{array}$ & $\begin{array}{c}-0.050 \\
(0.000)\end{array}$ & $\begin{array}{c}-0.051 \\
(0.000)\end{array}$ & $\begin{array}{c}-0.054 \\
(0.000)\end{array}$ & $\begin{array}{c}-0.149 \\
(0.000)\end{array}$ & $\begin{array}{c}-0.185 \\
(0.000)\end{array}$ \\
\hline $\begin{array}{l}\text { NPL } \\
\text { ( } p \text { value) }\end{array}$ & $\begin{array}{c}-0.018 \\
(0.017)\end{array}$ & $\begin{array}{c}-0.028 \\
(0.001)\end{array}$ & $\begin{array}{c}-0.111 \\
(0.000)\end{array}$ & $\begin{array}{c}-0.116 \\
(0.000)\end{array}$ & $\begin{array}{c}0.021 \\
(0.051)\end{array}$ & $\begin{array}{c}-0.034 \\
(0.001)\end{array}$ \\
\hline $\begin{array}{l}\text { LNTA } \\
\text { ( } p \text { value) }\end{array}$ & $\begin{array}{c}-0.057 \\
(0.000)\end{array}$ & $\begin{array}{c}-0.026 \\
(0.000)\end{array}$ & $\begin{array}{c}-0.012 \\
(0.072)\end{array}$ & $\begin{array}{c}0.005 \\
(0.472)\end{array}$ & $\begin{array}{c}-0.084 \\
(0.000)\end{array}$ & $\begin{array}{c}0.095 \\
(0.000)\end{array}$ \\
\hline $\begin{array}{l}\text { AGR } \\
\text { ( } p \text { value) }\end{array}$ & & $\begin{array}{c}-0.008 \\
(0.000)\end{array}$ & & $\begin{array}{c}-0.005 \\
(0.000)\end{array}$ & & $\begin{array}{c}-0.049 \\
(0.000)\end{array}$ \\
\hline Adjusted $\mathrm{R}^{2}$ & 0.03 & 0.07 & 0.03 & 0.05 & 0.02 & 0.15 \\
\hline
\end{tabular}

Panel B: Falling Interest Rate era, 2000:Q4-2002: Q4 (5,773 observations)

Dependent Variable

\begin{tabular}{|c|c|c|c|c|c|c|}
\hline \multirow[b]{3}{*}{ Variable } & \multirow{2}{*}{\multicolumn{2}{|c|}{ Change in NIM }} & \multirow{2}{*}{\multicolumn{2}{|c|}{ Change in ROA }} & & \\
\hline & & & & & \multicolumn{2}{|c|}{ Change in BVE } \\
\hline & Model 1 & Model 2 & Model 1 & Model 2 & Model 1 & Model 2 \\
\hline $\begin{array}{l}\text { Intercept } \\
\text { ( } p \text { value) }\end{array}$ & $\begin{array}{c}-0.285 \\
(0.005)\end{array}$ & $\begin{array}{c}-0.467 \\
(0.000)\end{array}$ & $\begin{array}{c}-0.311 \\
(0.002)\end{array}$ & $\begin{array}{c}-0.303 \\
(0.004)\end{array}$ & $\begin{array}{c}-0.488 \\
(0.000)\end{array}$ & $\begin{array}{c}-1.773 \\
(0.000)\end{array}$ \\
\hline $\begin{array}{l}\text { EVE } \\
\text { ( } p \text { value) }\end{array}$ & $\begin{array}{c}0.155 \\
(0.000)\end{array}$ & $\begin{array}{c}0.152 \\
(0.000)\end{array}$ & $\begin{array}{c}0.086 \\
(0.000)\end{array}$ & $\begin{array}{c}0.086 \\
(0.000)\end{array}$ & $\begin{array}{c}0.058 \\
(0.000)\end{array}$ & $\begin{array}{c}0.037 \\
(0.000)\end{array}$ \\
\hline $\begin{array}{l}\text { NPL } \\
\text { ( } p \text { value) }\end{array}$ & $\begin{array}{c}-0.013 \\
(0.266)\end{array}$ & $\begin{array}{c}-0.028 \\
(0.020)\end{array}$ & $\begin{array}{c}-0.116 \\
(0.000)\end{array}$ & $\begin{array}{c}-0.115 \\
(0.000)\end{array}$ & $\begin{array}{c}0.029 \\
(0.014)\end{array}$ & $\begin{array}{c}-0.071 \\
(0.000)\end{array}$ \\
\hline $\begin{array}{l}\text { LNTA } \\
\text { ( } p \text { value) }\end{array}$ & $\begin{array}{c}-0.001 \\
(0.945)\end{array}$ & $\begin{array}{c}0.025 \\
(0.012)\end{array}$ & $\begin{array}{c}0.025 \\
(0.006)\end{array}$ & $\begin{array}{c}0.024 \\
(0.018)\end{array}$ & $\begin{array}{c}0.056 \\
(0.000)\end{array}$ & $\begin{array}{c}0.235 \\
(0.000)\end{array}$ \\
\hline $\begin{array}{l}\text { AGR } \\
\text { ( } p \text { value) }\end{array}$ & & $\begin{array}{c}-0.007 \\
(0.000)\end{array}$ & & $\begin{array}{c}0.000 \\
(0.770)\end{array}$ & & $\begin{array}{c}-0.052 \\
(0.000)\end{array}$ \\
\hline Adjusted $\mathrm{R}^{2}$ & 0.09 & 0.11 & 0.07 & 0.07 & 0.00 & 0.15 \\
\hline
\end{tabular}

NOTE: We regress three different measures of ex post interest rate sensitivity on the Fed's ex ante measure of interest rate sensitivity (EVE), nonperfoming loans (NPL), log of total assets (LNTA) and asset growth rate (AGR). The three dependent variables are change in net interest margin (NIM), change in return on assets (ROA), and change in book value of equity (BVE). The coefficient on the EVE variable is the focus of the regression analysis.

We divide the sample period into two eras. The first era is from the fourth quarter of 1998 through the fourth quarter of 2000 and is a time period during which interest rates were more-or-less uniformly increasing. The second era is from the fourth quarter of 2000 through the fourth quarter of 2002 and is a time period during which interest rates were more-or-less uniformly falling. Banks that the Fed's model predicts are more liability sensitive should perform worse over the rising rate era, and the EVE coefficients in Panel A should be negative, which they are. Banks that the Fed's model predicts are more liability sensitive should perform better over the decreasing rate era, and the EVE coefficients in Panel B should be positive, which they are. P values are corrected for heteroskedasticity. 
(Panel A) experiences a 5.0-basis-point drop in NIM. However, in the falling rate era (Panel B) a bank with an EVE score 1 percentage point higher than another bank experiences a NIM increase of 15.5-basis-point increase, 3.1 times the change in the rising rate era. Moreover, ROA in the falling rate era increased by 1.6 times ( 8.6 divided by 5.4 ) the change in the rising rate era. The BVE results, however, do not show the same pattern in magnitude between Panels A and B. The EVE coefficient for the BVE in the falling rate era changed by just 0.2 times the change in the rising rate era.

With a few exceptions, the coefficients on the control variables have the expected signs. Nonperforming loan coefficients are negative in 10 of 12 regressions and statistically significant at the 5 percent level or lower in 9 regressions. The coefficients on bank size (natural log of total assets) suggest that, all else equal, larger banks have amplified swings in income and equity relative to smaller banks. With three exceptions, the coefficients on the natural log of total assets are negative in the rising rate era and positive in the falling rate era, implying that NIM, ROA, and BVE at the larger banks move in the same direction as the interest rate risk. Finally, the coefficients on asset growth are negative and statistically significant in the rising rate era, but remain negative in the falling rate era for all the specifications except that with ROA as the dependent variable. These results suggest that asset growth increased interest rate sensitivity in the rising rate era but partially offset the interest rate sensitivity in the falling rate era.

\section{Matched-Pairs Analysis}

Although regression analysis describes the average relationship between EVE and accounting performance measures, we are also interested in the ordinal properties of the EVM. Can the EVM separate the riskiest banks from the safer ones? This question is important to Federal Reserve examiners and supervisors because they use the model to help assess interest rate risk at a large number of community banks. The model may help them detect banks in the riskiest tail of the distribution.

We begin the matched-pairs analysis by separating the same sample of community banks used in the regression analysis into deciles based on their predicted exposure to rising interest rates as measured by their average EVE score. We then compare changes in the performance measures across deciles.
By grouping the banks into deciles, we are exploring whether the EVM broadly ranks banks by interest rate risk, allowing for the possibility that the ordinal rankings within a given decile may not be very tight. Banks that are the most liability sensitive are in the top deciles, whereas banks with low liability sensitivity or those that are asset sensitive (exposed to falling rates) are in the bottom deciles. This ranking does not imply that banks in the bottom deciles have low interest rate risk because such banks may be extremely asset sensitive. Interest rate risk is best captured by the absolute value of the EVE measure.

We compare bank performance in the top decile (the most liability-sensitive banks) with banks in consecutively lower deciles. Based on two characteristics, each bank in the top decile is matched with banks in lower deciles. Total assets at the match bank must be within 50 percent of the sample bank to control for the influence of size on performance ratios, and the nonperforming loan-to-total-asset ratios must be within 12.5 basis points to ensure that differences in nonaccruing loans do not unduly account for the banks' differences in NIM and ROA. If several banks qualify as matches with a bank in the top decile, we average the performance ratios of the matching banks.

To visualize the different reactions to falling interest rates, we plot in Figure 2 the average cumulative change in NIM by quarter of the banks in the top decile and the average cumulative change in NIM of the banks in the bottom decile. The average NIM at the most liability-sensitive banks declines during the first three quarters - probably due to the lag from the rising interest rate environment in 2000 - and then begins to climb in the third quarter of 2001. In contrast, the average NIM at the least liability-sensitive banks declines continuously between the fourth quarter of 2000 and the fourth quarter of 2002. By the fourth quarter of 2002, the difference in the change in NIM between the top decile and the bottom decile is about 78 basis points. Most of that difference is due to falling NIMs at the least liability-sensitive banks; rising NIMs at the most liability-sensitive banks account for only about 10 basis points of the total difference.

In addition to Figure 2, we conduct a series of $t$-tests on the differences in means between the most liability-sensitive banks and progressively less liability-sensitive match-banks, for both the rising interest rate environment and the falling interest rate environment. The results appear in Table 4. Panel A 


\section{Figure 2}

\section{Changes in NIM at EVE-Predicted High- and Low-Liability-Sensitive Banks}

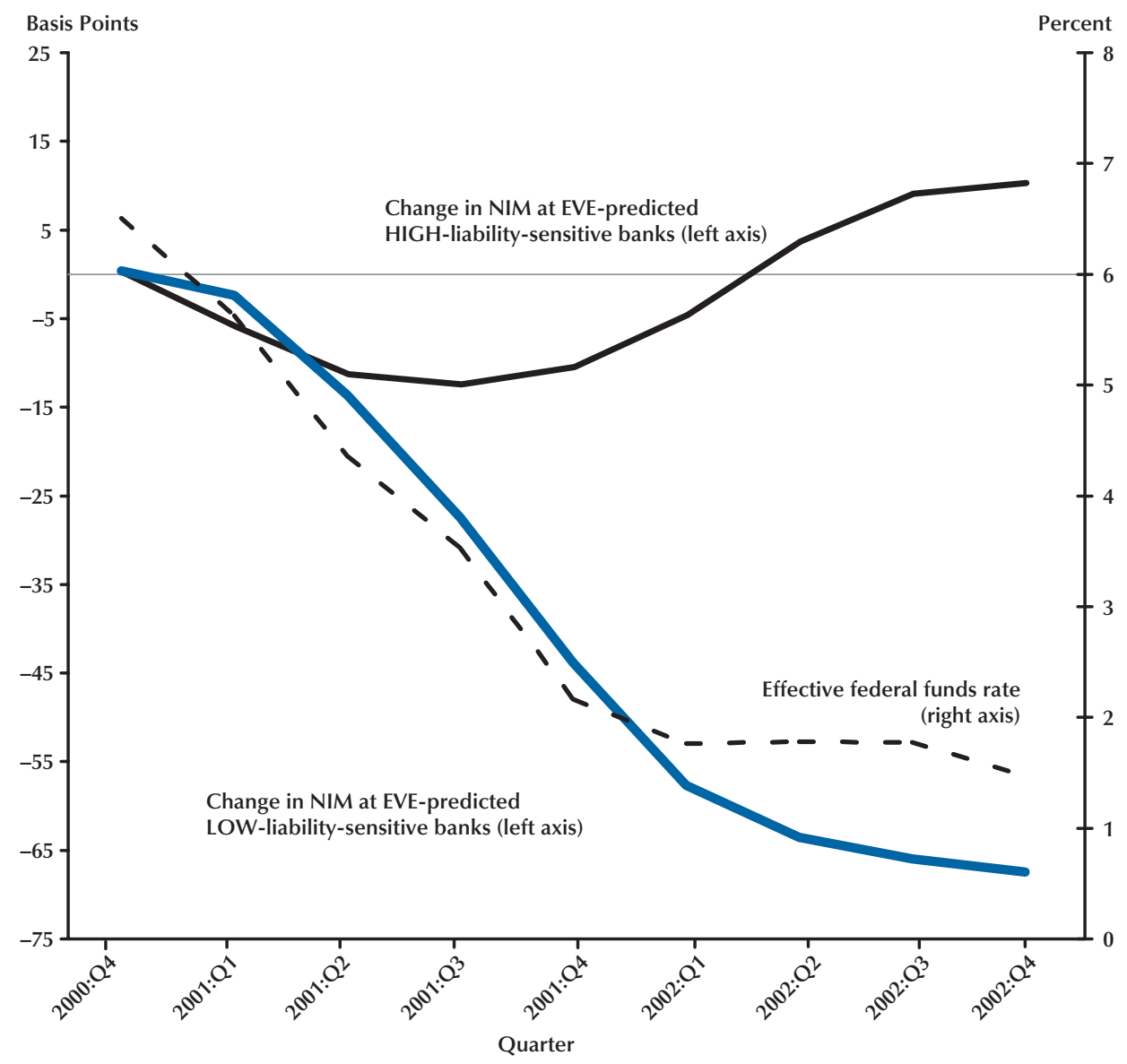

NOTE: We plot the average cumulative change in net interest margin (NIM) for high-EVE and lowEVE banks for the falling rate time period. The figure shows that high-EVE banks are indeed more liability sensitive than low-EVE banks. Furthermore, the direction of change is consistent with the EVM predictions; high-EVE banks' NIMs improve, while low-EVE banks' NIMs decrease. The chart also plots the effective federal funds rate on the right axis.

lists the results for the rising rate era, whereas Panel B lists the results for the falling rate era. The first row of each panel compares the average changes in NIM, ROA, and BVE of banks in the top (tenth) decile with the average changes for banks in the ninth decile; the second row compares the top decile with the eighth decile; and so on. We expect the differences to widen as the deciles in the comparison widen.

With some notable exceptions, the matched-pair results indicate that the Fed's EVM detects relatively fine quantitative differences in interest rate risk across deciles. The distinctions are the most pronounced for NIM and ROA in the falling rate environ- ment, reported in Panel B of Table 4. We expect the differences in changes in NIM and ROA to widen (become more positive) as the deciles compared become more extreme, because banks that are less liability sensitive will respond less favorably to a drop in rates compared with banks that are more liability sensitive. Indeed, the spread does widen as the gaps between the deciles widen, and the differences in the changes are statistically different from zero at the 5 percent level or lower for every comparison. Differences in the changes of BVE are less robust. In fact, differences in BVE changes have the wrong signs in five of nine comparisons of Panel B. 


\section{Table 4}

Relative Interest Rate Sensitivity of Pairs Matched by Extremity of the Fed's EVE Model Interest Rate Sensitivity Prediction

Panel A: Rising interest rate era, 1998:Q4-2000:Q4

\begin{tabular}{|c|c|c|c|c|c|c|c|}
\hline Decile & $\mathbf{N}$ & $\begin{array}{c}\text { Change in } \\
\text { NIM }\end{array}$ & $\begin{array}{l}\text { Difference in } \\
\text { NIM changes }\end{array}$ & $\begin{array}{c}\text { Change in } \\
\text { ROA }\end{array}$ & $\begin{array}{l}\text { Difference in } \\
\text { ROA changes }\end{array}$ & $\begin{array}{c}\text { Change in } \\
\text { BVE }\end{array}$ & $\begin{array}{l}\text { Difference in } \\
\text { BVE changes }\end{array}$ \\
\hline $\begin{array}{r}10 \\
9\end{array}$ & 595 & $\begin{array}{r}-11.18 \\
-9.60\end{array}$ & -1.58 & $\begin{array}{l}-8.08 \\
-6.30\end{array}$ & -1.79 & $\begin{array}{r}-43.55 \\
-8.59\end{array}$ & $-34.96^{* * *}$ \\
\hline $\begin{array}{r}10 \\
8\end{array}$ & 595 & $\begin{array}{r}-11.30 \\
-8.58\end{array}$ & -2.72 & $\begin{array}{l}-8.29 \\
-3.37\end{array}$ & $-4.92^{* *}$ & $\begin{array}{l}-45.18 \\
-16.41\end{array}$ & $-28.77^{* * *}$ \\
\hline $\begin{array}{r}10 \\
7\end{array}$ & 598 & $\begin{array}{r}-10.92 \\
-5.05\end{array}$ & $-5.87^{* * *}$ & $\begin{array}{l}-8.13 \\
-3.11\end{array}$ & $-5.01^{* *}$ & $\begin{array}{r}-44.81 \\
-5.99\end{array}$ & $-38.81^{* * *}$ \\
\hline $\begin{array}{r}10 \\
6\end{array}$ & 594 & $\begin{array}{r}-11.04 \\
-6.57\end{array}$ & $-4.48^{* * *}$ & $\begin{array}{r}-8.48 \\
1.28\end{array}$ & $-9.76^{* * *}$ & $\begin{array}{r}-45.75 \\
-0.87\end{array}$ & $-44.88^{* * *}$ \\
\hline $\begin{array}{r}10 \\
5\end{array}$ & 599 & $\begin{array}{r}-10.98 \\
-3.70\end{array}$ & $-7.28^{* * *}$ & $\begin{array}{r}-8.25 \\
0.46\end{array}$ & $-8.70^{* * *}$ & $\begin{array}{r}-44.78 \\
-2.41\end{array}$ & $-42.37^{* * *}$ \\
\hline $\begin{array}{r}10 \\
4\end{array}$ & 595 & $\begin{array}{r}-10.85 \\
-4.08\end{array}$ & $-6.78^{* * *}$ & $\begin{array}{l}-7.76 \\
-1.34\end{array}$ & $-6.42^{* * *}$ & $\begin{array}{r}-44.40 \\
2.40\end{array}$ & $-46.79 * * *$ \\
\hline $\begin{array}{r}10 \\
3\end{array}$ & 597 & $\begin{array}{r}-11.16 \\
6.46\end{array}$ & $-17.63^{* * *}$ & $\begin{array}{r}-8.44 \\
4.57\end{array}$ & $-13.02^{* * *}$ & $\begin{array}{r}-43.69 \\
7.56\end{array}$ & $-51.24 * * *$ \\
\hline $\begin{array}{r}10 \\
2\end{array}$ & 598 & $\begin{array}{r}-11.05 \\
1.32\end{array}$ & $-12.37^{* * *}$ & $\begin{array}{r}-7.89 \\
4.43\end{array}$ & $-12.32^{* * *}$ & $\begin{array}{r}-42.86 \\
8.24\end{array}$ & $-51.10 * * *$ \\
\hline $\begin{array}{r}10 \\
1\end{array}$ & 597 & $\begin{array}{r}-10.97 \\
12.72\end{array}$ & $-23.68^{* * *}$ & $\begin{array}{l}-8.79 \\
14.78\end{array}$ & $-23.57^{* * *}$ & $\begin{array}{r}-43.49 \\
35.80\end{array}$ & $-79.29 * * *$ \\
\hline
\end{tabular}

Panel B: Falling interest rate era, 2000:Q4-2002:Q4

\begin{tabular}{|c|c|c|c|c|c|c|c|}
\hline Decile & $\mathbf{N}$ & $\begin{array}{c}\text { Change in } \\
\text { NIM }\end{array}$ & $\begin{array}{l}\text { Difference in } \\
\text { NIM changes }\end{array}$ & $\begin{array}{c}\text { Change in } \\
\text { ROA }\end{array}$ & $\begin{array}{l}\text { Difference in } \\
\text { ROA changes }\end{array}$ & $\begin{array}{c}\text { Change in } \\
\text { BVE }\end{array}$ & $\begin{array}{l}\text { Difference in } \\
\text { BVE changes }\end{array}$ \\
\hline $\begin{array}{r}10 \\
9\end{array}$ & 571 & $\begin{array}{l}9.72 \\
4.02\end{array}$ & $5.70^{* *}$ & $\begin{array}{r}14.33 \\
8.50\end{array}$ & $5.82^{* * *}$ & $\begin{array}{l}25.34 \\
32.68\end{array}$ & -7.34 \\
\hline $\begin{array}{r}10 \\
8\end{array}$ & 569 & $\begin{array}{r}9.93 \\
-1.21\end{array}$ & $11.14^{* * *}$ & $\begin{array}{r}14.74 \\
7.14\end{array}$ & $7.59 * * *$ & $\begin{array}{l}25.22 \\
26.26\end{array}$ & -1.04 \\
\hline $\begin{array}{r}10 \\
7\end{array}$ & 570 & $\begin{array}{r}9.84 \\
-5.19\end{array}$ & $15.03^{* * *}$ & $\begin{array}{r}14.71 \\
3.39\end{array}$ & $11.32^{* * *}$ & $\begin{array}{l}24.90 \\
29.03\end{array}$ & -4.12 \\
\hline $\begin{array}{r}10 \\
6\end{array}$ & 567 & $\begin{array}{l}10.09 \\
-6.65\end{array}$ & $16.75^{* * *}$ & $\begin{array}{r}14.92 \\
4.93\end{array}$ & $9.99 * * *$ & $\begin{array}{l}25.31 \\
32.65\end{array}$ & -7.33 \\
\hline $\begin{array}{r}10 \\
5\end{array}$ & 572 & $\begin{array}{r}9.78 \\
-8.37\end{array}$ & $18.15^{* * *}$ & $\begin{array}{r}14.53 \\
1.25\end{array}$ & $13.28^{* * *}$ & $\begin{array}{l}25.00 \\
20.16\end{array}$ & $4.84^{* *}$ \\
\hline $\begin{array}{r}10 \\
4\end{array}$ & 572 & $\begin{array}{r}9.67 \\
-19.17\end{array}$ & $28.85^{* * *}$ & $\begin{array}{r}14.37 \\
1.25\end{array}$ & $13.11^{* * *}$ & $\begin{array}{l}24.99 \\
23.90\end{array}$ & 1.09 \\
\hline $\begin{array}{r}10 \\
3\end{array}$ & 569 & $\begin{array}{r}9.93 \\
-16.66\end{array}$ & $26.59 * * *$ & $\begin{array}{r}14.55 \\
-0.46\end{array}$ & $15.01^{* * *}$ & $\begin{array}{l}25.09 \\
15.14\end{array}$ & 9.95 \\
\hline $\begin{array}{r}10 \\
2\end{array}$ & 572 & $\begin{array}{r}9.34 \\
-33.81\end{array}$ & $43.15^{* * *}$ & $\begin{array}{r}14.26 \\
-9.38\end{array}$ & $23.64 * * *$ & $\begin{array}{l}24.69 \\
10.06\end{array}$ & $14.63^{*}$ \\
\hline $\begin{array}{r}10 \\
1\end{array}$ & 571 & $\begin{array}{r}10.19 \\
-65.79\end{array}$ & $75.98^{* * *}$ & $\begin{array}{r}14.45 \\
-28.76\end{array}$ & $43.21^{* * *}$ & $\begin{array}{l}25.18 \\
-2.56\end{array}$ & $27.74 * * *$ \\
\hline
\end{tabular}

NOTE: Values are in basis points. */***** indicate significance at the 10/5/1 percent levels, respectively. In this table, we divide community banks into deciles based upon their degree of liability sensitivity. We then match banks in the top decile with similar banks in the lower decile. With few exceptions, we find that the more liability-sensitive banks perform more poorly in the rising rate era, but they perform better in the falling rate era. These results show that the Fed's EVM accurately separates banks by their interest rate sensitivity. The banks in the higher (lower) deciles are predicted to be the most (least) liability sensitive. 
Only for three of the comparisons in Panel B are the results statistically significant and have the expected sign.

The matched-pair results for NIM and ROA in the rising rate era are not as dramatic as the results in the falling rate era, but the results for the BVE are much stronger than those of the falling rate era. The rising rate era results appear in Panel A of Table 4. We expect the differences in the changes in NIM, ROA, and BVE to become more negative as the decile comparisons widen, because the most liability-sensitive banks in the top decile should have larger declines in these performance measures relative to less liability-sensitive banks. All of the differences of the changes in NIM, ROA, and BVE have the expected signs, and they generally become more negative as the decile differences widen. In addition, most are statistically significant at the 1 percent level. Results for the BVE show that banks in the top decile experienced a drop in equity of 43.55 basis points, whereas banks in the ninth decile had a drop in equity of 8.59 basis points. The -34.96 -basis-point difference is statistically significant at the 1 percent level. The differences in the changes of BVE generally become more negative, as expected, such that the spread between the top and bottom deciles is more than -79 basis points.

In sum, matched-pair analysis indicates that the Fed's EVM can detect differences in interest rate risk when banks are grouped by deciles according to their exposure to rising interest rates. These results confirm the robustness of the regression results and suggest that bank supervisors can use the EVM as a useful tool to rank community banks by interest rate sensitivity.

\section{Correlation with the "S" Rating}

Each time a bank is examined, examiners assign the bank a sensitivity (S) rating from 1 to 5, with 1 being the best rating. A strong and positive correlation between the EVE score and the S rating would be consistent with the assertion that the EVM captures information about a bank's interest rate risk. This analysis also serves as a robustness check against the prior tests, which rely solely on accounting numbers.

We assess the correlation between EVE and S ratings both in decile groupings and on a bank-bybank basis. As with matched pairs, the decile analysis allows for the possibility that the EVE rankings within a given decile may not be very tight. We rank all the community banks in our sample by their EVE scores and split the banks into deciles. We then compute the mean EVE and S ratings and rank the deciles by the absolute value of each decile. If the EVE model is calibrated such that banks with the lowest interest rate risk have EVE scores near zero, then banks with large absolute-value EVE scores should have relatively worse (higher) examiner ratings. The top half of Table 5 lists the mean EVE score and the mean S rating for each decile, listed in descending order by the absolute value of the mean EVE score.

The correlation coefficients listed in the bottom half of Table 5 show a consistent positive relationship between the absolute value of EVE scores and $S$ ratings. The correlation coefficient on a decile basis is 0.99 , and it is 0.14 on a bank-by-bank basis. Both are statistically different from zero at the 1 percent level. The high degree of correlation suggests that either the EVM captures information about interest rate risk that examiners confirm on site or the examiners use the EVM to help assess interest rate risk.

Even though Federal Reserve examiners are instructed not to incorporate the EVM directly into the $S$ rating, one may be skeptical. One simple test to help discern the direction of causation between EVE and S ratings is to examine the correlation between EVE scores and S ratings in 1998. Because 1998 was the first year that the Focus reports were made available to examiners, a period of transition undoubtedly took place for the examiners to learn about and understand the report. A positive correlation in 1998 would add to the evidence that the EVM captures information that examiners confirm on site. At the bottom of Table 5 we report the correlation coefficient between EVE scores and S ratings assigned in 1998. The decile correlation is 0.82 and the bank-level correlation is 0.10 . Again, both are statistically different from zero at the 1 percent level. The results for 1998 lend support to the hypothesis that the EVM contains information about interest rate sensitivity that examiners affirm when they are on site at a particular bank.

\section{CONCLUSION}

Regression analysis, matched pairs, and correlation analysis demonstrate that the Fed's EVM is a useful supervisory tool to assess the relative interest rate risk at community banks. Bank supervisors can confidently use the model's output to rank banks by interest rate sensitivity. The model appears to be quite stable and robust. Although the EVM was 


\section{Table 5}

\section{The Relationship Between the EVM and the "S" Ratings}

\begin{tabular}{cccc}
$\begin{array}{c}\text { Decile by } \\
\text { absolute value of EVE }\end{array}$ & Mean S rating by decile & Mean EVE of decile & Observations \\
\hline 10 & 1.83 & 3.44 & 3,716 \\
9 & 1.73 & 2.22 & 3,715 \\
8 & 1.67 & 1.68 & 3,715 \\
7 & 1.64 & 1.28 & 3,715 \\
6 & 1.62 & -1.12 & 3,715 \\
5 & 1.61 & 0.95 & 3,715 \\
4 & 1.56 & 0.64 & 3,715 \\
3 & 1.58 & -0.37 & 3,715 \\
2 & 1.56 & 0.34 & 3,715 \\
1 & 1.56 & 0.02 & 3,715
\end{tabular}

Correlation coefficient of absolute value of EVE and $S$ ratings

\begin{tabular}{lcc} 
& By decile & Bank level \\
\cline { 2 - 3 } Full sample & $0.99^{* * *}$ & $0.14^{* * *}$ \\
1998 & $0.82^{* * *}$ & $0.10^{* * *}$
\end{tabular}

NOTE: ***Indicates significance at the 1 percent level or better. We measure the correlation between the absolute value of the EVE measure and a bank's S rating. The EVE measure and S ratings are positively correlated at a decile and bank level. The results show that either the Fed's EVM identifies interest rate risk patterns that examiners confirm on site or that examiners use the EVM to assign the $\mathrm{S}$ rating.

constructed assuming a parallel yield curve shift upward of 200 basis points, our results demonstrate that the model is useful in both rising and falling interest rate eras and in time periods in which the slope of the yield curve changes.

Another conclusion that emerges from these results is that the average interest rate risk at community banks appears to be modest. Even relatively big changes in interest rates such as the drop that occurred between December 2000 and December 2002 had relatively small effects on income and capital at community banks, both in absolute and relative terms. For example, regression analysis predicts that the average bank with an EVE score of 0.99 experienced an increase in NIM of about 15 basis points, an increase in ROA of 9 basis points, and an increase in BVE of 4 basis points over the twoyear period of falling rates. Although nontrivial, none of these changes by themselves are of sufficient magnitude to affect bank performance significantly. Consequently, interest rate risk does not appear to be a significant threat to bank safety and soundness at the present time, a conclusion that should provide some comfort to monetary policymakers when they influence interest rates.

One caveat to this conclusion is that our analysis fails to consider the interaction between interest rate risk and other risks, such as credit risk. A large change in the level of interest rates may affect community banks more severely than our analysis suggests because the default rates of marginal borrowers with variable rate payments may increase.

\section{REFERENCES}

Aharony, Joseph and Saunders, Anthony. "The Effects of a Shift in Monetary Policy Regime on the Profitability and Risk of Commercial Banks." Journal of Monetary Economics, May 1986, 17(3), pp. 363-77.

Curry, Timothy and Shibut, Lynn. "The Cost of the Savings and Loan Crisis: Truth and Consequences." FDIC Banking Review, December 2000, 13(2), p. 26-35.

Flannery, Mark J. “Market Interest Rates and Commercial 
Bank Profitability: An Empirical Investigation." Journal of Finance, December 1981, 36(6), pp. 1085-101.

Flannery, Mark J. "Interest Rates and Bank Profitability: Additional Evidence." Journal of Money, Credit and Banking, August 1983, 15(3), pp. 355-62.

Flannery, Mark J. and James, Christopher M. "Market Evidence of the Effective Maturity of Bank Assets and Liabilities." Journal of Money, Credit, and Banking, November 1984, 16(4, Part 1), pp. 435-45.

Gilkeson, James H.; Hudgins, Sylvia C. and Ruff, Craig K. "Testing the Effectiveness of Regulatory Interest Rate Risk Measurement." Journal of Economics and Finance, Summer 1997, 21(2), pp. 27-37.

Houpt, James V. and Embersit, James A. "A Method for Evaluating Interest Rate Risk in U.S. Commercial Banks." Federal Reserve Bulletin, August 1991, pp. 625-37.

Lumpkin, Stephen A. and O'Brien, James M. “Thrift Stock Returns and Portfolio Interest Rate Sensitivity." Journal of Monetary Economics, July 1997, 39(2), pp. 341-57.

Robinson, Kenneth J. "Interesting Times for Banks Since Basle.” Financial Industry Studies, July 1995, pp. 9-16.
Robinson, Kenneth J. and Klemme, Kelly. "Does Greater Mortgage Activity Lead to Greater Interest Rate Risk? Evidence from Bank Holding Companies." Financial Industry Studies, August 1996, pp. 13-24.

Saunders, Anthony and Yourougou, Pierre. "Are Banks Special? The Separation of Banking from Commerce and Interest Rate Risk." Journal of Economics and Business, May 1990, 42(2), pp. 171-82.

Saunders, Anthony and Cornett, Marcia. Financial Institutions Management. Fourth Edition. McGraw-Hill Irwin, 2003.

Sierra, Gregory E. "Can an Accounting-Based Duration Model Effectively Measure Interest Rate Sensitivity?" Ph.D. Dissertation, Washington University, April 2004.

Wright, David M. and Houpt, James V. "An Analysis of Commercial Bank Exposure to Interest Rate Risk." Federal Reserve Bulletin, February 1996, 82(2), pp. 115-28.

Yourougou, Pierre. "Interest Rate Risk and the Pricing of Depository Financial Intermediary Common Stock." Journal of Banking and Finance, October 1990, 14(4), pp. 803-20. 